\title{
IMPLEMENTING ADVERTISEMENT FOR IMPROVING STUDENTS' UNDERSTANDING OF POLITENESS AND GENDER
}

\author{
Vina Fathira \\ English Letters Department, STIBA Persada Bunda Pekanbaru, Indonesia \\ Email: vinafathira@gmail.com; vinafathira@persadabunda.ac.id \\ Silvia Utami \\ English Letters Department, STIBA Persada Bunda Pekanbaru, Indonesia \\ Email: silvia.utami@persadabunda.ac.id
}

\begin{abstract}
APA Citation: Fathira, V., \& Utami, S. (2019). Implementing advertisement for improving students' understanding of politeness and gender. English Review: Journal of English Education, 7(2), 143-150. doi: 10.25134/erjee.v7i2.1460.
\end{abstract}

\begin{abstract}
This research was based on students' difficulties in understanding the concept of politeness and gender. Advertisement can be one of the alternative techniques to improve students' understanding on the concept of politeness and gender. This study aims at improving students' understanding of politeness and gender and finding the factors influencing the improvement. This Classroom Action Research involved ten third-year-students at STIBA Persada Bunda Pekanbaru. The data collection techniques used were tests, fieldnotes, observation, and interview. The results showed that students' understanding of politeness and gender significantly improved after applying advertisements in the teaching and learning process in which the students' understanding which were at the low level category increases to the good level category. Some factors affecting the students' improvement were students' active participation in obtaining information and students' enthusiasm during the learning process. In conclusion, the implementation of advertisements can improve students' understanding of politeness and gender concepts.
\end{abstract}

Keywords: advertisement; negative and positive face; politeness and gender; politeness strategies; sociolinguistic; women's language.

\section{INTRODUCTION}

Media like advertisements are familiar to the students nowadays. As the technology is growing, the social media has become the routine to everyone; the students are seen addicted to the gadget (Siddiqui \& Singh, 2016). In advertisement, advertising can be divided in animation, videos, and moving pictures (Harfoushi et al., 2016). In this research, the researchers took internet advertisements, since advertisements related to electronic items were more factual than non-electronic items (Bansal \& Gupta 2014). Advertsing language is the language that can persuade and provoke society's opinion to certain purposes of an advertisement (Stamatelou, 2015).

Sociolingustics is a branch of linguistics that studies a relationship between language and society (Holmes \& Wilson, 2017). Meanwhile, literally, sociolinguistics is the study of the way language is affected by differences in social class, region, sex and so on (Hornby, 2018). Actually, sociolinguistic is a subject which is easy to understand since it is related to the social environment. However, the students always felt difficult to understand such definitions and examples given in the text book. One of the materials in sociolinguistics that is considered difficult is the concept of politeness and gender.

According to Holmes and Wilson (2017), polite includes talking to others in an appropiate way. Politeness is the basic point to asses' someone's habit to others to be accepted and approved by others as part of habits of norms (Culpeper, Haugh \& Kádár, 2017). In politeness concept, there is a concept of face proposed by Brown and Levinson. According to them, face consists of two parts, namely positive and negative face (Pangestuti, 2015; Wardhaugh \& Fuller, 2014). Positive face is a concept of politeness theory that relates to someone's willingness to be approved and admired by others (Hameed, 2010; Wardhaugh \& Fuller, 2015). Meanwhile, negative face is a term of politeness theory that relates to someone's unwillingness to be approved and admired by others (Wardhaugh \& Fuller, 2015).

In Brown and Levinson's theory, there are some strategies used in politeness, namely bald 
on-record strategy, positive politeness strategy, negative politeness strategy, and off-record indirect strategy (Karimkhanlooei \& Vaezi, 2017; Pangestuti, 2015).

Different from the concept of politeness, the concept of gender cannot be easily defined as a social construction of identity that relates to the thought of biological category of "sex", but it frequently discussess about 'masculinity' and 'feminity' that in opposite with 'male' and 'female' (Meyerhoff, 2018; Strumska-Cylwik \& Ibrahim, 2014). However, the concept of gender related to linguistic aspect is defined as linguistic features in conncetion with the way of a group or certain gender in speaking (Wardhaugh \& Fuller, 2015). In line with this, Culpeper, Haugh and Kádár (2017) define gender as an assumption or thought about the differences of men and women habits.

The term gender is social and cultural category (Hornby, 2018). As stated by Holmes and Wilson (2017), the concept of gender focuses on description of habitual utterances of masculine and feminism, in certain scale not in absolute category. The differences of it can be seen in the features of women's language by Lakoff's theory. Based on Lakoff's theory, there are 10 features of women's language (2013).

Thus, the aims of the research were to find out the improvement of students' ability and to identify the factors affecting the improvement of students' ability at STIBA Persada Bunda Pekanbaru in understanding politeness and gender concept of sociolinguistic subject by implementing advertisement as media in the teaching and learning process.

\section{METHOD}

This Classroom Action Research was started by preliminary study, such as gaining information concerning students' understanding of politeness and gender concept. After doing the preliminary study, the researchers did some stages, including planning, acting, observing, and reflecting. This research was conducted at STIBA Persada Bunda. The participants of this research were the third year students of STIBA Persada Persada Bunda in the academic year of 2017/2018 attending sociolinguistic subject.

The data collection techniques used were tests, fieldnotes, observation, and interview. To obtain data related to students' understanding of politeness and gender concept, the students were asked to answer a set of multiple choice questions after watching two videos of advertisements relating to politeness and gender. The test aims to evaluate the improvement of the students' ability in understanding politeness and gender concept by using media of advertisement. Then, the researcher and collaborator wrote students' activities by using fieldnotes and obeservation checklist. After that, the researchers conducted interview to all students to obtain data about the factors affecting the improvement of the students' ability in understanding politeness and gender concept. After collecting the data, the researchers evaluate and analyze post-test by counting the number of correct answers and calculating it to the final score (post-test) of each student.

Table 1. Score range and category

\begin{tabular}{llc}
\hline No. & Range score & Category \\
\hline 1 & $80-100$ & Very Good \\
2 & $65-79$ & Good \\
3 & $55-64$ & Fairly Good \\
4 & $<55$ & Poor \\
\hline
\end{tabular}

(Taken from: Persada Bunda score range)

\section{RESULTS AND DISCUSSION}

This section generally describes the aforementioned stages done which include planning, acting, observing, and reflecting. The stages were done in 5 meetings. Besides, there was 1 meeting for pre-test and 1 meeting for post-test.

Meeting for pre-test

In this meeting, the researcher did a pre-test to the students. The test aims to know the students' ability in understanding the concept of politeness and gender. The test showed that the students' ability in understanding the concept of politeness and gender was in poor category in which the students' score was 51.49.

The result of the $1^{\text {st }}$ meeting

Previously, the researchers had been looking for information about the students' ability in understanding the concept of politeness and gender. 
Then, at this first meeting, the teaching-learning process was preceded by an introduction to the students about the concept of politeness and gender. Here, the researchers asked questions related to the concept of politeness and gender. After that, the researchers gave the examples of the concept of politeness and gender to the students. Moreover, the students were asked to give other examples of politeness and gender. The researchers asked students to write down everything that belongs to the features of women's language from Lakoff theory.

The result of the $2^{\text {nd }}$ meeting

In the second meeting, the researchers explained the concept of politeness and gender by using advertisement. First, the researchers introduced the advertisement media in the form of videos with duration lenght about 2-3 minutes which consisted of linguistic feature of women's language. After that, the researchers asked students in pairs to watch carefully and take a note as much as possible indicating politeness and gender. Besides, the students were also asked to determine the linguistic features of women's language, negative or positive face, and the politeness strategy appeared in the first advertisements. Then, the researchers asked students to watch again the advertisement and another advertisement at home as individual assignment by focusing on the aspects, like women's language, negative face or positive face, and politeness strategy existed in the advertisements. The assignment must be written per point by showing the utterances that met the features of women's language based on Lakoff's theory.

The result of the $3^{\text {rd }}$ meeting

In the third meeting, the students were asked to submit the assignments given at the previous meeting. After that, the researchers gave response to the results of students' assignments by explaining the fetaures of women's language of each point that students found, the existence of negative or positive face on the advertisements, and the politeness strategy. After giving comments and inputs towards the students' assignments, the researchers instructed students to think of their mistakes by watching the advertisement back, paid attention to the utterances, and the politeness and gender concept well. This process aimed to eliminate misunderstandings in understanding the features of women's language, the existance of negative or positive face on the advertisement, and the politeness strategy appeared in advertisement.

\section{The result of the $4^{\text {th }}$ meeting}

In the fourth meeting, the teaching-learning process focused on showing the results of the two advertisements that had been observed previously. It could be an overview to make students more understand about what they did. In this meeting, the students were asked to show their assignments in front of the class.

The result of the $5^{\text {th }}$ meeting

In this meeting, the researcher and collaborator grade the students' work related to their understanding of the ten features of woman's language, namely; a) Lexical hedges or fillers, b) Tag questions, c) Rising intonations on declaratives, d) 'Empty' adjectives, e) Precise color teams, f) Intensifiers, such as just and so, g) 'Hypercorrect' grammar, h) 'Superpolite' forms, i) Avoidance of strong swears words, and j) Emphatic stress. In addition, the advertisement was analyzed to find out the positive face, negative face and politeness with regard to some strategies, such as: a) bald on-record strategy, b) positive politeness strategy, c) negative politeness strategy, and d) off-record indirect strategy. Based on these points, the students had obtained enough information regarding the politeness and gender concept existed in advertisement. From these components, the researcher grade and convert the students' result by looking at the score range category.

Meeting for post-test

In the last meeting, the post-test was conducted by asking the students to to analyze two different advertisements with longer duration (3 minutes). This test was conducted to measure the students' imporvement in understanding the concept of politeness and gender. The post-test result is presented in Table 2.

Table 2. The post test result

\begin{tabular}{ccc}
\hline No. & Score & Category \\
\hline 1 & 65,4 & Good \\
2 & 69,2 & Good \\
3 & 69,2 & Good \\
4 & 61,5 & Good \\
5 & 69,2 & Good
\end{tabular}




\begin{tabular}{ccc}
6 & 73,1 & Good \\
7 & 73,1 & Good \\
8 & 73,1 & Good \\
9 & 88,5 & Very good \\
10 & 88,5 & Very good \\
\hline \multicolumn{2}{r}{ Mean $=73,08$} & Good \\
\hline
\end{tabular}

\section{Students' Achievement}

Based on the analysis, it was found that the mean score from the pre-test was 51.49 which belonged to the poor category. However, after conducting the research by using advertisements for five meetings ( 1 cycle), the students' mean score was significantly increases. The mean score was 73.08 which belonged to the good category.

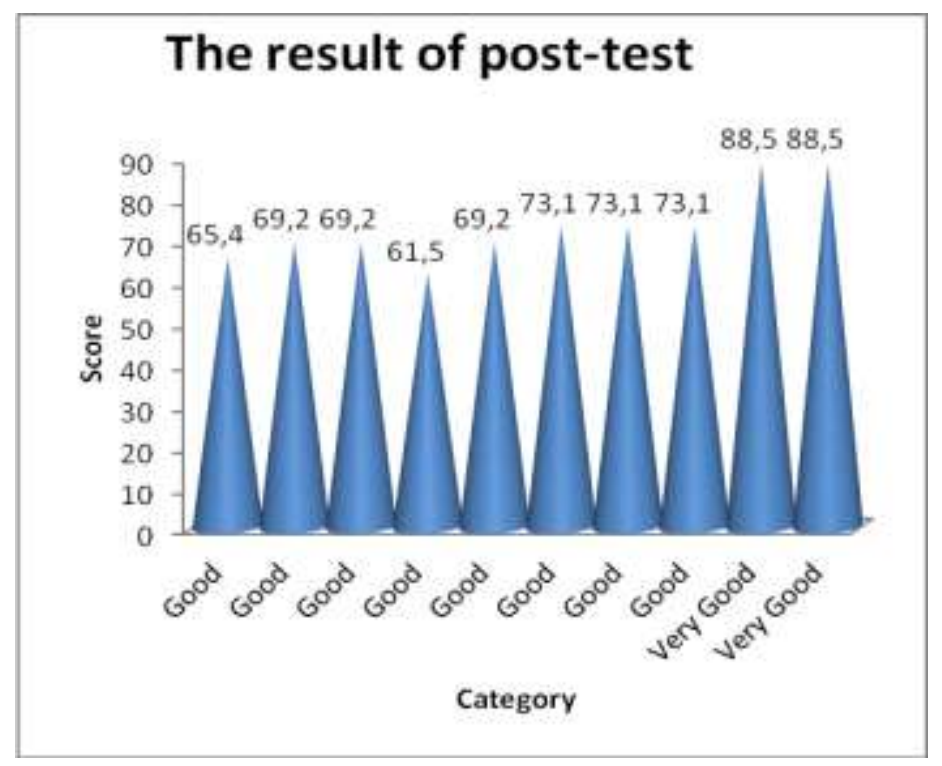

Figure 2. The result of post-test

Moreover, the researcher found that the students have lack of understanding about the concept of politeness and gender that could be seen from the resut of pre-test. Most students got low score that categorized as poor with percentage of $90 \%$. Meanwhile, one student was categorized as fairly good with percentage of $10 \%$. The result can be seen in Table 3 .

Table 3. The result of pre-test

\begin{tabular}{ccc}
\hline No & Score & Category \\
\hline 1. & 61,5 & Fairly good \\
2 & 46,1 & Poor \\
3 & 53,8 & Poor \\
4 & 46,1 & Poor \\
5 & 53,8 & Poor \\
6 & 53,8 & Poor \\
7 & 53,8 & Poor \\
8 & 46,1 & Poor \\
9 & 53,8 & Poor \\
10 & 46,1 & Poor \\
\hline \multicolumn{2}{l}{ Mean score $=51,49$} & Poor \\
\hline
\end{tabular}

The scores obtained from the correct answer is divided by the number of questions then multiplied by 10 . From the data above, it can be seen that only one student who got fairly good with score 61.5. Meanwhile, nine students were categorized as poor, as depicted below. 


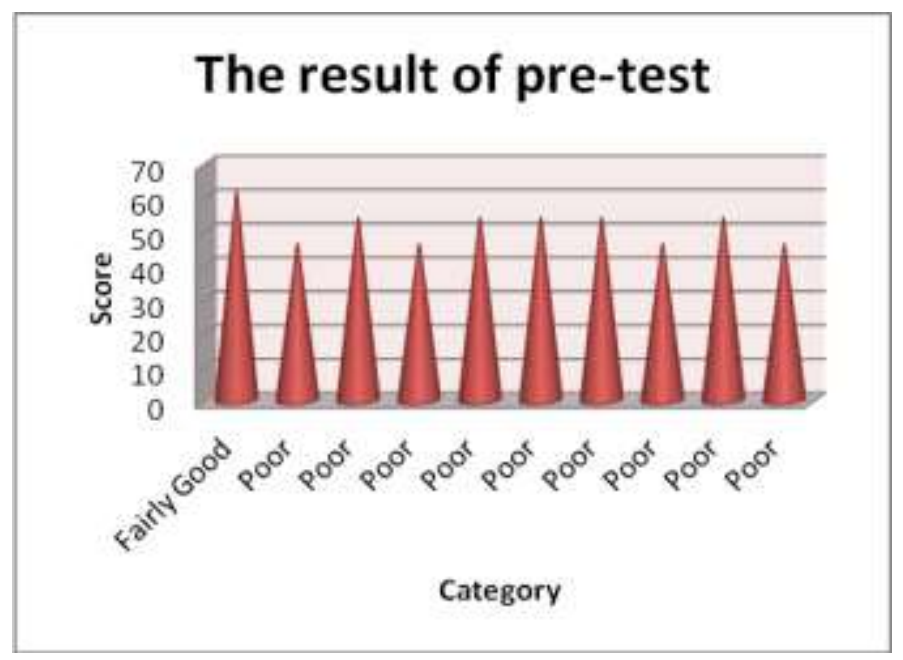

Figure 3 . The result of pre-test

From Figure 3, it can be seen that there were four students who got 46.1 and five students got 53.8. Then, the cycle test found that the students' mean score was categorized as good. It showed that 8 out of 10 students had good category and 2 students had very good category. It was significantly increases than the pre-test in which one student had fairly good result out of 10 students, while 9 students were categorized as poor. The comparison of students' score in the pre-test and post-test is shown in Table 3.

Table 3. The comparison of students' score

\begin{tabular}{cccl}
\hline No & Test & $\begin{array}{c}\text { Total of } \\
\text { Participant }\end{array}$ & \multicolumn{1}{c}{ Category } \\
\hline 1. & Pre-test & 1 & Fairly good \\
& & 9 & Poor \\
\hline & & 2 & Very good \\
2. & Post-test & 8 & Good \\
\hline
\end{tabular}

Referring to the table, the result of cycle test after using advertisement to improve students' understanding towards the concept of politeness and gender based on the components can be seen clearly in the following diagram. In this diagram, the researchers described both tests and the improvement of the cycle test compared to the pre-test.

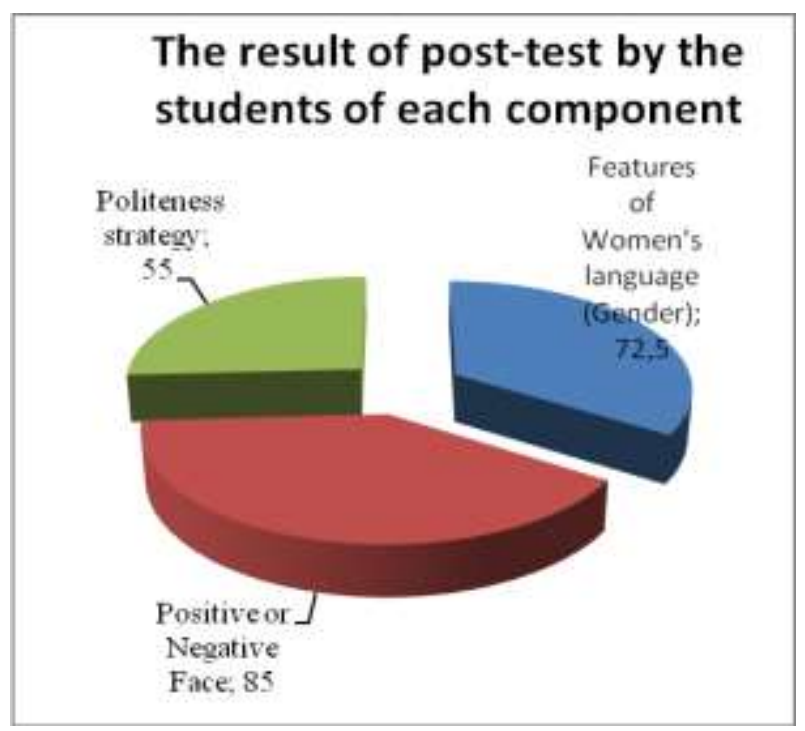

Figure 4. The result of students' post-test in each component 
Figure 4 showed that the result of students' cycle test was satisfactory. The components assessed are politeness strategy, positive or negative face that represented the concept of politeness, and the features of woman's language that represented the concept of gender. Figure 4 showed that the score from these components was fairly good. The cycle test result from the features of woman's language that represented the concept of gender was categorized as very good with the score of 72.5. Then, the two components, politeness strategy and positive or negative face, that represented the concept of politeness showed fairly good scores. On the positive or negative face components, the score of cycle test was categorized as very good with the score of 85 . Then, in the component of politeness strategy, the score of the cycle test was 55 which categorized as fairly good.

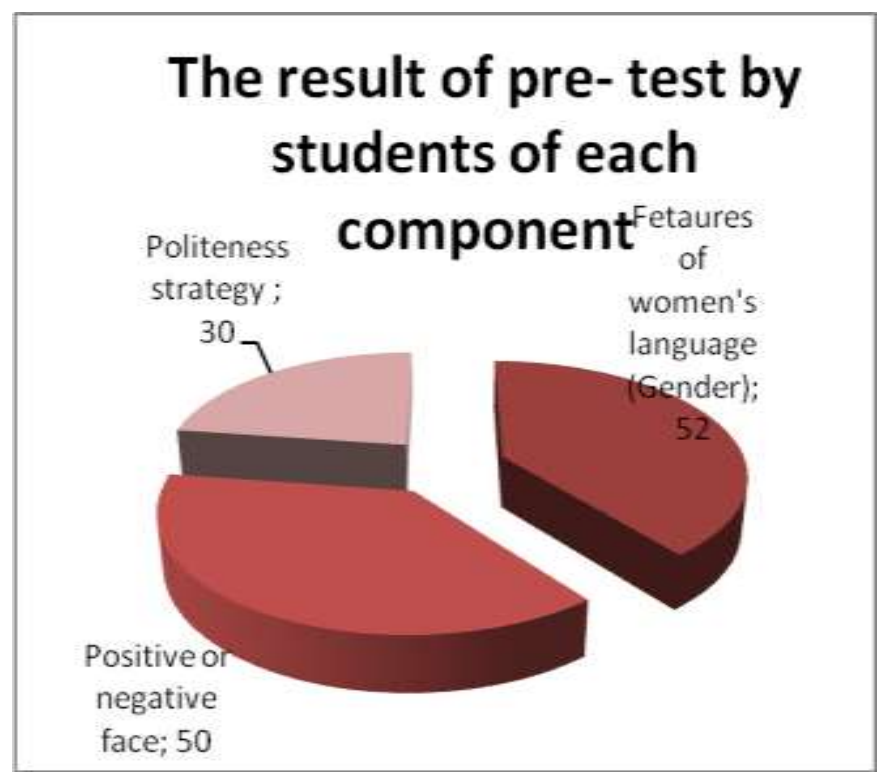

Figure 5. The result of students' pre-test in each component

The two Figures above showed the students' improvement that can be seen from the score of each component. On the component of the features of women's language (gender), the score in the pre-test showed 52 with "low" category (poor). This score was significantly increases with a better score of 72.5 on the "very good" category in the cycle test. On the positive face and negative face components, the score of the pre-test showed 50 with "low" category (poor). This score was also significantly increases with a better score of 85 categorized as "very good". On the component of politeness strategy, the score in pre-test showed 30 with "low" category (poor) and significantly increased to 55 with "fairly good" category.

Based on the data, it was clear that the scores from each component showed significant increases. The increase was a student achievement from the pre-test results to the cycle test. The students' cycle test score was much higher than the pre-test score. Thus, it can be concluded that there has been an increase in students' ability in understanding the concept of politeness and gender by using media of advertisement. In other words, it can be argued that the implementation of media of advertisement can help students to better understand the concept of politeness and gender.

\section{Factors influencing students' improvement}

Furthermore, based on observation, it was found that every stage of this research was well done by students. Then, during the interview, information was found that most students were active in obtaining information and enjoyed during the learning process. However, there was one student who was bored due to the length of time in the advertisement and the topic of advertisement that the student did not like. It showed that there were other factors that influence the student's understanding in the concept of politeness and genders and the factors that affected the student in the activity during learning process other than the test results.

Based on the results obtained in this first cycle, the researcher stated that the students' ability in understanding the concept of politeness and gender with the implementation of media of advertisement in sociolinguistic class was 
categorized into good category. Therefore, the researcher decided not to continue the research into the next cycle because of the discovery of the suitability between the achievement and the specified successfull criteria.

\section{CONCLUSION}

Based on the data analysis, it can be concluded that the implementation of advertisement media can improve students' understanding of the concept of politeness and gender. First, the students' mean score was 73.08 is categorized into the good category. This is based on ranges of 65-79 that categorized as "good". Second, the factors that influenced the improvement of students in understanding the concept of politeness and gender are the students feel interested by using this advertisement. In addition, the students are active and enthusiastic in determining the concept of politeness and gender in sociolinguistic studies which are usually boring. Third, only a few students get bad scores. This happened due to the duration of the advertisements that was too long causing a small number of students feel tired dan being sleepy when watching the advertisements on cycle tests with a duration of 2 (two) minutes and 3 (three) minutes. Fourth, in this research, only some features of Lakoff's theories of women's language are found in advertisements so that students sometimes still feel hesitant about the results. This is in line with the research conducted by Aini (2016). Fifth, generally, media of advertisement often use a similar strategy, like a positive politeness strategy which is in line with the findings of Pangestuti (2015), Elmianvari and Kheirabadi (2015), and Wambui (2014) which used a positive politeness strategy. Sixth, in relation to the results of the above points (point 5), the researcher then conduct a qualitative research that focuses on the concept of politeness with deeper analysis. Seventh, the future researcher needs to explore non-video media of advertisement regarding to the same concept of politeness and gender.

\section{ACKNOWLEDGMENTS}

The team is very grateful to Kemenristekdikti which in this occasion gives researchers the opportunity to publish the research findings to an accredited journal. The findings of this study are part of Hibah Dikti, namely Penelitian Dosen Pemula 2018. In addition, researchers thank the team member and research assistants who have been actively involved in the completion of this research.

\section{REFERENCES}

Aini, L. M. (2016). Women language used by the main characters of "Mockingjay" movie. UnpublishedThesis. English Language and Letters Department: Maulana Malik Ibrahim State Islamic University of Malang.

Bansal, M., \& Gupta, S. (2014). Impact of newspaper advertisement on consumer behavior. Global Journal of Finance and Management, 6(7), 669674.

Culpeper, J., Haugh, M., \& Kádár, D. Z. (Eds). (2017). The palgrave handbook of linguistic (im)politeness. London: Palgrave Macmillan.

Elmianvari \& Kheirabadi. (2015). The study of EFL students' requests based on politeness theory. Journal of Language Teaching and Research, 4(2), 375-385.

Hameed, W. Q. (2010). The impact of gender in determining politeness strategy with reference to Iraqi students of English. Journal of the College of Arts, 54(2), 38-56.

Harfoushi O., Alfawwaz, B., Obeidat, B., Obeidat, R., \& Faris, H. (2013). Impact of internet advertisement and its features on e-commerce retail sales: Evidence from Europe. Journal of Software Engineering and Applications, 6, 564570.

Holmes, J., \& Wilson, N. (2017). Learning about language: An introduction to sociolinguistics. Essex: Pearson Education Ltd.

Hornby, A. S. (2018). Oxford learners' dictionary (Online). Retrieved from https://www.oxfordlearnersdictionaries.com/defi nition/english/a-s-hornby.

Karimkhanlooei, G., \& Vaezi, N. (2017). Politeness strategies in written communications: The issue of Iranian EFL learners. Jolace: Journal of Language and Cultural Education, 5(3), 108126. doi: $10.1515 /$ jolace-2017-0031.

Meyerhoff, M. (2018). Introducing sociolinguistics $\left(3^{\text {rd }}\right.$ ed. $)$. New York: Routledge.

Pangestuti, W. (2015). Politeness strategies used by Deddy Corbuzier in interviewing entertainer and nonentertainer in "Hitam Putih" talk show. Unpublished Thesis. English Department: University of Diponegoro.

Siddiqui, S., \& Singh, T. T. (2016). Social media and its impact with positive and negative aspects. International Journal of Computer Applications Technology and Research, 5(2), 71-75.

Stamatelou, M. (2015). A reflection on the use of Advertisements in enabling language learning in the EFL classroom. Elted, 17, 27-34.

Strumska-Cylwik, L., \& Ibrahim, F. (2014). Gender relationship and media language: A comparative study of print media in Poland and Malaysia. 


\section{Vina Fathira \& Silvia Utami}

Implementing advertisement for improving students' understanding of politeness and gender

International Journal of Arts \& Sciences, 7(5), 647-682.

Wambui, N. S. (2014). Linguistic politeness strategies in bank advertisements: A case study of Kenya commercial bank. Unpublished Thesis.
Department of Linguistics and Languages: University of Nairobi.

Wardhaugh, R., \& Fuller, J. M. (2015). An introduction to sociolinguistics $\left(7^{\text {th }}\right.$ ed.). Oxford: Wiley Blackwell. 